\section{Simplified AFLP \\ Protocol: Replacement of \\ Primer Labeling by the \\ Incorporation of \\ $\alpha$-Labeled Nucleotides during PCR}

\section{BioTechniques 28:622-623 (April 2000)}

Over the last few years, PCR-based technologies have become established as systems for genetic mapping and fingerprinting in a variety of organisms $(1,8,9)$. AFLP (7) is a recently developed multilocus marker technique that has been widely used for identifying polymorphisms in both prokaryotic and eukaryotic organisms $(3,4,6)$. In AFLP, a subset of restriction fragments from a genomic DNA digest is selectively amplified in the PCR. The technique does not require prior knowledge of DNA sequences and has proved to be both robust and reliable because it uses stringent reaction conditions.

According to the standard AFLP protocol (7), fingerprints are visualized by end-labeling one of the AFLP primers with polynucleotide kinase and $\gamma-\left[{ }^{32} \mathrm{P}\right]-\mathrm{dATP}$ or $\gamma-\left[{ }^{33} \mathrm{P}\right]-\mathrm{dATP}$. A commercially available AFLP kit (AFLPTM Analysis System I; Life Technologies, Rockville, MD, USA) is also based on primer end-labeling. We found that the primer labeling step can be omitted when $\alpha$-labeled nucleotides are incorporated into PCR products during amplification. This simplification of the protocol proves particularly useful when a large number of primers have to be screened for suitability to generate polymorphisms and/or when $\alpha$-labeled nucleotides are available for other purposes. Here, we describe a protocol for setting up AFLP analysis without primer labeling and without relying on commercial kits.

In the original AFLP protocol (7), genomic DNA is digested with EcoRI and MseI. We used Tru1I (MBI Fermentas, St. Leon-Rot, Germany) as an economical substitute for MseI (both enzymes cleave the sequence /AATT). To simplify the protocol, both enzymes were added at the same time, and the reaction mixture was incubated succes-

Table 1. Sequence of AFLP-Adapters Used in this Study

\begin{tabular}{|cc|}
\hline ECORI adapter: & 5'-CTCGTAGACTGCGCGTACC-3' \\
& 3'-CATCTGACGCGCATGGTTAA-5' $^{\prime}$ \\
TrulI adapter: & 5'-GACGATGAGTCCTGAG-3' \\
& 3'-TACTCAGGACTCAT-5' $^{\prime}$ \\
\hline
\end{tabular}

sively at $37^{\circ} \mathrm{C}$ (the optimal temperature for $E c o \mathrm{RI}$ ) and at $65^{\circ} \mathrm{C}$ (optimum for Tru1I). To illustrate our protocol, 200 ng of DNA extracted from the tissue of Lymantria dispar (Lepidoptera, Lymantriidae) and purified using spermine precipitation (5) were restricted with $10 \mathrm{U}$ EcoRI (Amersham Pharmacia Biotech, Freiburg, Germany) and 1 $\mathrm{U}$ Tru $1 \mathrm{I}$ in $1 \times \mathrm{R}$ buffer (both from MBI Fermentas) in the presence of 0.1 $\mathrm{mg} / \mathrm{mL}$ BSA for $1.5 \mathrm{~h}$ at $37^{\circ} \mathrm{C}$, followed by $1.5 \mathrm{~h}$ at $65^{\circ} \mathrm{C}$ in a total volume of $10 \mu \mathrm{L}$. Added to the digested DNA were $1 \mathrm{pM}$ of both EcoRI and Tru1I oligonucleotide adapters (see Table 1), ligation buffer and 0.25 U T4 DNA ligase (both from US Biochemicals, Cleveland, OH, USA). The solution was incubated at $20^{\circ} \mathrm{C}$ for $2 \mathrm{~h}$ and diluted tenfold with TE buffer $(10 \mathrm{mM}$ Tris-HCl, pH 8.0, 0.1 mM EDTA).

Similar to the original protocol, PCR was performed in two steps: (i) pre-amplification with primers corresponding to the EcoRI and Tru1I adapters and (ii) selective amplification with primers prolonged by 1 to 3 nucleotides. For the preamplification, $27 \mathrm{ng}$ of EcoRI primer (5'-GACTGCGTACCAATT-3') and 30 ng of Tru1I primer (5'-GATGAGTCCTGAGTAA-3') were mixed with $1 \mu \mathrm{L}$ of diluted ligated DNA, $1 \times$ AFLP buffer (10 mM Tris- $\mathrm{HCl}, \mathrm{pH} 8.3,1.5 \mathrm{mM}$ $\left.\mathrm{MgCl}_{2}, 50 \mathrm{mM} \mathrm{KCl}, \mathrm{pH} 8.3\right), 0.1 \mathrm{mM}$ dNTPs (Amersham Pharmacia Biotech) and 0.2 U Taq DNA polymerase (MBI Fermentas) in a total volume of $5 \mu \mathrm{L}$. The samples were incubated in a PTC$100^{\mathrm{TM}}$ thermal cycler (MJ Research, Watertown, MA, USA) for 20 cycles that consisted of $94^{\circ} \mathrm{C}$ for $30 \mathrm{~s}, 56^{\circ} \mathrm{C}$ for $1 \mathrm{~min}$ and $72^{\circ} \mathrm{C}$ for $1 \mathrm{~min}$. After the preamplification step, the PCR products were diluted 50-fold with TE buffer and further used for selective amplification.

Selective amplification with the incorporation of $\alpha-\left[{ }^{33} \mathrm{P}\right]-\mathrm{dATP}$ was carried out in a total reaction volume of 5 $\mu \mathrm{L}$ containing $1.25 \mu \mathrm{L}$ diluted, pre-amplified template DNA, 1× AFLP buffer,
$10 \mu \mathrm{M}$ dATP, $0.1 \mathrm{mM}$ each of dCTP, dGTP and dTTP, 0.2 U Taq DNA polymerase, $2.7 \mathrm{ng}$ and $7.6 \mathrm{ng}$ of selective EcoRI and Tru1I primers, respectively, and $0.5 \mu \mathrm{Ci} \alpha-\left[{ }^{33} \mathrm{P}\right]-\mathrm{dATP}(3000$ $\mathrm{Ci} / \mathrm{mM}$; Amersham Buchler, Braunschweig, Germany). The PCR temperature profile began with one cycle at $94^{\circ} \mathrm{C}$ for $30 \mathrm{~s}, 65^{\circ} \mathrm{C}$ for $30 \mathrm{~s}$ and $72^{\circ} \mathrm{C}$ for 1 min. The annealing temperature was then lowered by $0.7^{\circ} \mathrm{C}$ for each of $12 \mathrm{cy}$ cles, followed by 23 cycles at $94^{\circ} \mathrm{C}$ for $30 \mathrm{~s}, 56^{\circ} \mathrm{C}$ for $1 \mathrm{~min}$ and $72^{\circ} \mathrm{C}$ for $1 \mathrm{~min}$.

After amplification, the samples were denatured by adding an equal volume $(5 \mu \mathrm{L})$ of formamide buffer (97.95\% formamide, $0.025 \%$ xylene cyanol FF, $0.025 \%$ bromophenol blue and $2 \%$ of $0.5 \mathrm{M}$ EDTA, pH 8.0) and heating for $3 \mathrm{~min}$ at $80^{\circ} \mathrm{C}$. Four microliters of the samples were loaded on a $5 \%$ denaturing polyacrylamide gel and electrophoresed in $1 \times$ TBE buffer $(0.1$ $\mathrm{M}$ Tris-HCl, $0.1 \mathrm{mM}$ EDTA, $\mathrm{pH}$ 8.0) at $50 \mathrm{~W}$ for $1.5 \mathrm{~h}$ in a $40 \mathrm{~cm}$ long electrophoretic chamber (Sequencing gel electrophoresis apparatus; Life Technologies). The gel was dried for $40 \mathrm{~min}$ at $70^{\circ} \mathrm{C}$ in a gel dryer (Bio-Rad Laboratories, Hercules, CA, USA), exposed to a phospho-imaging screen (Fujifilm Imaging Plate ${ }^{\mathrm{TM}}$; raytest, Straubenhardt, Germany) for approximately 18 $\mathrm{h}$ and scanned using a Fujifilm Bioimaging Analyzer System ${ }^{\mathrm{TM}}$ (BAS1000); raytest.

Using the above protocol with the incorporation of $\alpha-\left[{ }^{33} \mathrm{P}\right]-\mathrm{dATP}$, AFLP fingerprints of insect and fungal genomes displaying large numbers of DNA polymorphisms were successfully generated (data not shown). No differences in the banding pattern were observed between products radiolabeled using end-labeled primers and those visualized by the incorporation of $\alpha-\left[{ }^{3} \mathrm{P}\right]-\mathrm{dATP}$ during PCR (data not shown). Our modification of the original procedure by Vos et al. (7) has several advantages: $(i)$ incorporation labeling results in a reduction of the required 


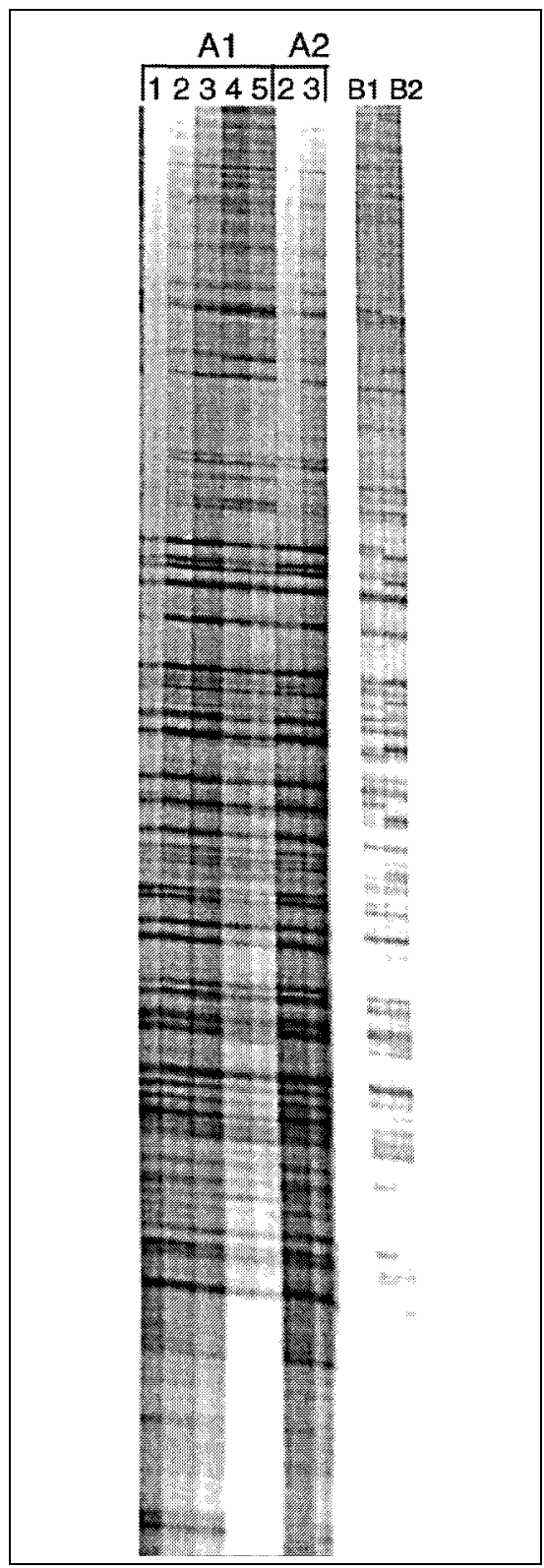

Figure 1. Effect of the dNTP concentration on AFLP fingerprints radiolabeled by the incorporation of $\alpha-\left[{ }^{33} \mathbf{P}\right]-\mathbf{d A T P}$. Template DNA of one Lymantria dispar individual was amplified with primer combinations EcoRI with selective nucleotides +AGG and Tru1I with selective nucleotides $+\mathrm{CT}$ at various concentrations of dNTPs in the selective amplification step. The reactions were conducted with $0.1 \mathrm{mM}$ (lane A1) and $0.2 \mathrm{mM}$ (lane A2) of each dTTP, dGTP and dCTP. The amount of dATP was varied as follows: lane $1,1 \mu \mathrm{M}$; lane $2,5 \mu \mathrm{M}$; lane $3,10 \mu \mathrm{M}$; lane $4,50 \mu \mathrm{M}$ and lane $5,100 \mu \mathrm{M}$. Lane B shows AFLP products of two $L$. dispar individuals (B1 and B2) using Tru1I (MseI) primer from the kit AFLP Analysis System I. MseI primer solutions from this kit contain dNTPs at $0.2 \mathrm{mM}$ each. AFLP products were radioactively labeled by incorporation of $\alpha-\left[{ }^{33} \mathrm{P}\right]-\mathrm{dATP}$ during the specific amplification and separated on a 5\% denaturing polyacrylamide gel. amount of the radioactive isotope $(0.5$ $\mu \mathrm{Ci} \alpha-\left[{ }^{33} \mathrm{P}\right]-\mathrm{dATP}$ per reaction) as compared to the original procedure (1 $\mu \mathrm{Ci} \gamma$-[ $\left.{ }^{33} \mathrm{P}\right]$-dATP per reaction) (7); (ii) compared to the conditions recommended by Life Technologies, the reaction volume is considerably reduced, which results in a lower consumption of reaction components; and (iii) since primer labeling and purification are spared, the total amount of time for performing an AFLP analysis is reduced.

The modified protocol as described worked reliably. However, alterations of the amount of "cold" dATP may alter the efficiency of the amplification reaction and result in bands of varying intensity (Figure 1). Small fragments are prominent at a low concentration of dATP $(1 \mu \mathrm{M})$, and large fragments are visible at higher dATP concentrations $(50-100 \mu \mathrm{M})$. It is likely that Taq DNA polymerase does not finish the extension of long products under conditions of low dATP concentrations and short extension times, which prevents the products from exponential amplification. This results in an under-representation of long fragments in AFLP patterns under these conditions. Based on our empirical data, the following concentrations of $10 \mu \mathrm{M}$ dATP and $0.1 \mathrm{mM}$ each of dGTP, dCTP and dTTP are recommended for optimal results. AFLP primers supplied with the AFLP System I cannot be used with this protocol because dNTPs are supplied in the same solution as one of the primers at equimolar concentrations of $0.2 \mathrm{mM}$. Therefore, the use of this kit in combination with incorporation-labeling results in inferior AFLP patterns, as demonstrated in Figure 1, lanes B1 and B2.

\section{REFERENCES}

1.Caetano-Anollés, G., B.J. Bassam and P.M. Gresshoff. 1991. DNA fingerprinting using very short arbitrary oligonucleotide primers. Biotechnology 9:553-557.

2.Folkertsma, R.T., J.N.A.M. van der Voort, K.E. de Groot, P.M. van Zandvoort, A. Schots, F.J. Gommers, J. Helder and J. Bakker. 1996. Gene pool similarities of potato cyst nematode populations assessed by AFLP analysis. Mol. Plant Microbe Interact. 9:47-54.

3.Hill, M., H. Witsenboer, M. Zabeau, P. Vos, R. Kesseli and R. Michelmore. 1996. PCRbased fingerprinting using AFLPs as a tool for studying genetic relationships in Lactuca spp. Theor. Appl. Genet. 93:1202-1210.
4.Janssen, P., R. Coopman, G. Huys, J. Swings, M. Bleeker, P. Vos, M. Zabeau and K. Kersters. 1996. Evaluation of the DNA fingerprinting method AFLP as a new tool in bacterial taxonomy. Microbiology 142:18811893.

5.Reineke, A., P. Karlovsky and C.P.W. Zebitz. 1998. Preparation and purification of DNA from insects for AFLP analysis. Insect Mol. Biol. 7:95-99.

6.Reineke, A., P. Karlovsky and C.P.W. Zebitz. 1999. Amplified fragment length polymorphism analysis of different geographic populations of the gypsy moth, Lymantria dispar (Lepidoptera: Lymantriidae). Bull. Entomol. Res. 89:79-88.

7.Vos, P., R. Hogers, M. Bleeker, M. Reijans, T. van de Lee, M. Hornes, A. Frijters, J. Pot et al. 1995. AFLP: A new technique for DNA fingerprinting. Nucleic Acids Res. 21:44074414.

8.Williams, J.G.K., A.R. Kubelik, K.J. Livak, J.A. Rafalski and S.V. Kingsey. 1990. DNA polymorphisms amplified by arbitrary primers are useful as genetic markers. Nucleic Acids Res. 18:6531-6535

9.Zietkiewicz, E., A. Rafalski and D. Labuda. 1994. Genome fingerprinting by simple sequence repeat (SSR)-anchored polymorphism chain reaction amplification. Genomics 20:176-183.

Address correspondence to Dr. Annette Reineke, University of Adelaide, Department of Applied and Molecular Ecology, Glen Osmond, SA 5064, Australia. Internet: areineke@waite.adelaide.edu.au

Date received 1 November 1999; accepted 9 December 1999.

\section{Annette Reineke and Petr Karlovsky University of Hohenheim Stuttgart, Germany}

